\title{
Internet risky behaviours among youth with visual impairment
}

\author{
Magdalena Wrzesińska ${ }^{\text {Corresp., } 1}{ }^{\text {, Kamila Knol-Michałowska }}{ }^{2}$, Patryk Stecz ${ }^{3}$, Monika Kopytowska ${ }^{4}$, Katarzyna Binder- \\ Olibrowska $^{5}$ \\ 1 Department of Psychosocial Rehabilitation, Medical University of Lodz, Lodz, Polska \\ 2 National Centre for Workplace Health Promotion, Nofer Institute of Occupational Medicine, Lodz, Poland \\ 3 Department of Clinical Psychology and Psychopathology, Institute of Psychology, Faculty of Educational Sciences, University of Lodz, Lodz, Poland \\ 4 Department of Pragmatics, Institute of English Studies, Faculty of Philology, University of Lodz, Lodz, Poland \\ 5 Department of Psychosocial Rehabilitation, Medical University of Lodz, Lodz, Poland \\ Corresponding Author: Magdalena Wrzesińska \\ Email address: magdalena.wrzesinska@umed.lodz.pl
}

Background: Young individuals with visual impairment (VI), exposed to higher risky of social exclusion, might be more prone to Internet risky behaviours including electronic aggression.

Objective:Different types of Internet risky behaviours and the average time spent online were investigated among students with VI. These behaviours were analyzed for the relationship with witnessing, perpetrating and becoming a victim of electronic aggression.

Methods:490 special needs school students with VI answered a self-administered questionnaire. The average time spent online, different types of risky Internet activities and electronic aggression were recorded, as well as sociodemographic characteristics.

Results:Male students downloaded software illegally, hacked, published and viewed sites with sexual content, and gambled online statistically more often than female counterparts. Concerning electronic aggression, more than half of participants were engaged as witnesses, every fifth student as a victim and $11.6 \%$ as perpetrators. Two sets of ordinal logistic regression analyses have shown that communication with a person promoting violence and an excessive amount of time spent online during weekends predicted significantly the risky of witnessing and being a victim of electronic aggression. Additionally, communicating with a person promoting violence and an excessive amount of time spent online during schooldays were associated with increased odds for engagement in electronic aggression as a perpetrator.

Conclusions:Population with VI is prone to risky Internet use and likely to be engaged in electronic aggression. New instruments and preventive strategies need to be developed, as well as diagnostic tools tailored specifically to the needs of young people with VI. 


\section{Internet risky behaviours among youth with visual impairment}

2 Magdalena Wrzesińska1 ${ }^{1}$ ORCID 0000-0002-3513-280X

3 Kamila Knol-Michałowska ${ }^{2}$ ORCID 0000-0002-8194-5019

4 Patryk Stecz ORCID ${ }^{3}$ 0000-0002-8291-9103

5 Monika Kopytowska ${ }^{4}$ ORCID 0000-0002-1065-7044

6 Katarzyna Binder-Olibrowska ${ }^{5}$, ORCID 0000-0003-3022-2440

$8 \quad{ }^{1}$ Department of Psychosocial Rehabilitation, Medical University of Lodz, Poland

$9{ }^{2}$ National Centre for Workplace Health Promotion, Nofer Institute of Occupational Medicine,

10 Lodz, Poland

$11{ }^{3}$ Department of Clinical Psychology and Psychopathology, Institute of Psychology, Faculty of

12 Educational Sciences, University of Lodz, Poland

$13{ }^{4}$ Department of Pragmatics, Institute of English Studies, Faculty of Philology, University of

14 Lodz, Poland

$15{ }^{5}$ Department of Psychosocial Rehabilitation, Medical University of Lodz, Poland

\section{Corresponding author}

19 Magdalena Wrzesińska, PhD, Medical University of Lodz

20 Head, Department of Psychosocial Rehabilitation

21 Mail: magdalena.wrzesinska@umed.lodz.pl

22 Lindleya 6

23 90-131 Lodz Poland 


\section{ABSTRACT}

34 Background: Young individuals with visual impairment (VI), exposed to higher risky of social 35 exclusion, might be more prone to Internet risky behaviours including electronic aggression.

Objective: Different types of Internet risky behaviours and the average time spent online were investigated among students with VI. These behaviours were analyzed for the relationship with witnessing, perpetrating and becoming a victim of electronic aggression. Methods: 490 special needs school students with VI answered a self-administered questionnaire. The average time spent online, different types of risky Internet activities and electronic aggression were recorded, as well as sociodemographic characteristics.

42 Results: Male students downloaded software illegally, hacked, published and viewed sites with 43 sexual content, and gambled online statistically more often than female counterparts. Concerning electronic aggression, more than half of participants were engaged as witnesses, every fifth student as a victim and $11.6 \%$ as perpetrators. Two sets of ordinal logistic regression analyses have shown that communication with a person promoting violence and an excessive amount of time spent online during weekends predicted significantly the risky of witnessing and being a victim of electronic aggression. Additionally, communicating with a person promoting violence and an excessive amount of time spent online during schooldays were associated with increased odds for engagement in electronic aggression as a perpetrator.

51 Conclusions: Population with VI is prone to risky Internet use and likely to be engaged in 52 electronic aggression. New instruments and preventive strategies need to be developed, as well as 53 diagnostic tools tailored specifically to the needs of young people with VI.

\section{KEYWORDS}

55 Online risky behaviours, visual impairment, youth, Internet 
Online activities play a crucial role in young people's daily life, transforming, both qualitatively and quantitively, the ways in which they socialize and learn $[1,2]$. One of the most important reports on youth's online activities has been developed as part of the EU Kids Online project. The main aim of this project is to provide high quality, independent and comprehensive research findings to improve the use and security of an online environment for young people. Surveys have been regularly conducted among school students for over a decade by research teams from 34 countries applying an integrated research expertise across multiple disciplines and methods. The project provides an opportunity to map youth's experience of online spaces including social and cultural aspects and it delivers the necessary information regarding cyberspace for practitioners as well as the national and international policy stakeholders [3]. According to the results of the last Polish EU Kids Online research almost half of young people use the Internet for up to 2 hours on schooldays and for up to 3 hours during weekends. Using social networking services (SNS) and video/audio conferencing tools, playing games, watching movies and listening to music are done most often every or almost every day by students [4]. The Internet, with multiple websites and applications allowing for a quick exchange of information, has become a learning tool and platform. As demonstrated by the EU KIDS report, $60 \%$ of school students use the Internet for doing homework, preparing for tests, and expanding knowledge needed for school [4]. There are, however, also negative aspects associated with Information and Communication Technologies (ICT) and digital communication. Tahiroglu et al. [5] argue that the Internet has a negative impact on young people's psychosocial development due to the fact that it is timeconsuming and uncontrollable. As posited by social compensation theory, negative life events can enhance motivation to go online to relieve negative feelings [6]. In this context, the Covid-19 pandemic and the resulting spatial distancing, along with the introduction of distance learning solutions, has caused anxiety, thus leading to excessive Internet use [7]. Despite enabling various 
91 activities, cyberspace with its technological affordances has also become an environment where

92 harmful and violent content of all kinds can be accessed, generated, amplified and distributed [8,9].

93 Electronic aggression is indeed one of the most important online phenomena to which young

94 Internet users are exposed. It is most often defined as actions which have been carried out against

95 the will of victims and caused social, psychological or moral harm. The concept of electronic 96 aggression is broad and it is significantly different than cyberbullying. The only thing that is 97 common to these two concepts is the use of ICT. The cyberbullying criteria, such as repeatability, 98 relation between a victim and a perpetrator (in cyberbullying it is the same social group, for 99 example school class, whereas in case of electronic aggression it is not specified - it can be both: 100 people that a perpetrator knows and strangers), aim of harming the victim and imbalance of 101 power do not apply in case of electronic aggression. In addition, electronic aggression can be used 102 both in a situation where an aggressive action is made directly against another person (e.g. sending 103 an offending e-mail), as well as when an action is indirect (e.g. compromising materials are 104 published in the Internet) [10]. A recent Polish study showed that among those who faced aggression off-line about $30 \%$ of youth have never been affected by aggression via the Internet, and also about every third person aged 9-17 has never been a perpetrator of electronic aggression.

107 On the other hand, about $14 \%$ of older students have received sexual messages and $7 \%$ of them 108 have been perpetrators of cyberbullying or hate speech [4].

109 As posited by Media Proximization Approach (MPA) the transgression of spatial and temporal 110 boundaries made possible thanks to the techno-discursive design of digital media (i.e. 111 technological aspects along with presumption-related discursive practices) [11] not only enables 112 and facilitates user-to-user interaction, but also allows users to access, generate and share media 113 content [12-15]. Interactivity and connectivity translate into greater emotional involvement. 114 Technically, the Internet and social media sometimes encourage the spread of emotionally loaded 115 content in a way that cannot be controlled [8]. Anonymity is a key factor here. The Social Identity 116 Model of Deindividuation Effects [16] points to serious cognitive consequences of anonymity in 117 online interactions including various forms of anti-social behaviour, such as flaming (posting 118 insults and other offensive language), trolling (posting inflammatory, digressive and off-topic 119 messages in a particular online community - forum, chat room, blog - with the intention of 120 provoking its members to respond in an emotional way) and other forms of online incivility 121 (various forms of offensive interaction including aggressive comments, hate speech and 
122 harassment) [17]. Deindividuation experienced due to perceived anonymity may thus enhance

123 disinhibition: individuals act like they would never do in face-to-face communication [14]. MPA

124 argues that technologically-enabled changes in distance dynamics (involving interactivity patterns

125 and anonymity), make potential victims of online aggression more accessible to perpetrators and

126 vulnerable to the attacks [15]. Likewise, they also make young Internet users more prone to online

127 risky behaviours, in terms of both exposure and performance. Mubarak classifies risk-

128 taking behaviours into three categories, namely dangerous interactions with people, accessing

129 dangerous websites and other risk-taking behaviours [18]. One of the most comprehensive

130 typologies of online risky behaviours was developed for the EU KIDS Online research [2, 19] and

131 adapted by Polish authors [20]. It includes two dimensions types of online activities (content-based

132 activities, contact- or communication-based activities, and conduct or peer-participation activities)

133 and types of risk (aggressive, sexual, values, and commercial). Numerous other studies

134 investigated youth in the context of cyber aggression or cyberbullying [21,22], sexually explicit

135 content [23, 24], and self-harm activities [25]. The factors that affect susceptibility to online risky

136 behaviours included age, gender, parental control, as well as parents' education level. Study results

137 showed that girls, older teenagers, and those whose parents have low education experience risky

138 online behaviours more frequently [26, 27]. Additionally, girls are more frequently exposed to

139 information about self-harming, ways of committing suicide or extreme weight loss, while boys

140 more often search for online pornography [24, 26]. The Internet use among people with disabilities

141 is correlated with age and more likely to occur among young people. Youth with a physical

142 disability are excluded from participation in the society because of restrictions in daily life, such

143 as self-care, reduced mobility, or communication activities. Hence, a number of studies discuss the

144 need for Internet use among young people with disabilities [28, 29]. The Internet has considerably

145 empowered this group thus enhancing the degree of its participation in the social life [30]. It has

146 become the main e-resource for students with VI because online activities give them an

147 opportunity to learn and work independently, when compared to traditional methods [31]. It should

148 be noted, however, that efficient and independent use of the Internet by people with VI often

149 requires additional optical equipment, hardware, and software in the form of screen readers,

150 magnifiers, or Braille monitors. Websites and mobile applications should comply with Web

151 Content Accessibility Guidelines (WACG), thus making the use of the Internet more user-friendly

152 and functional. Such solutions make it easier for people with VI to adjust page settings (eg. high 
153 contrast, larger font) to their needs in order to see the content better (both words and images). Still,

154 the adaptation of technological devices requires understanding of the specific problems of end-

155 users whose feedback is essential to develop personalized aids for the blind and poor-sighted [32].

156 Young people with chronic health diseases and disabilities are more likely to become victims of

157 peer harassment [33]. Previous Polish studies focused on the statistical relationship between cyber-

158 victimization and having problems with visible bodily injury and disability. Male students with

159 health problems were significantly more exposed to being a victim of both traditional bullying and

160 cyberbullying [34]. Negative body image, reduced self-esteem, decreased social and

161 communication skills or poor academic performance have been identified as the main predictors

162 of being the target of victimization in this group [35]. Although, the prevalence rate of bullying

163 depends on illness or disability, the highest risk of victimization was observed among youth with

164 VI [35]. Another preliminary study [36] also confirmed that students with VI spent more time on

165 online activities compared to their peers without disabilities. About three quarters of them used

166 the Internet for learning purposes and over 60\% spent their free time in social media. They were

167 also prone to on-line risky behaviours, with boys being more likely to download files illegally,

168 hack or watch pornography than girls.

169 However, the above-mentioned research was conducted among a small number of students with

170 disability and provides no details as regards the correlation between the specific online risky

171 behaviours and different types of electronic aggression. To fill the information gap in this area it

172 seems necessary to understand the motivations behind both risky behaviours and online aggression

173 among young people who are blind or poor-sighed $[34,36]$. Research in this area is essential and

174 highly relevant, especially when an offensive type of communication is correlated with stereotypes

175 including various social characteristics such as gender, religion, age, race or disability [34, 37].

176 For this reason, it is important to find answers to the main research questions: What is the

177 frequency and nature of Internet use among young people with VI? Are students with VI involved

178 in online risky behaviours? What kind of relations between online behaviours and manifestations

179 of electronic aggression (victim/witness/perpetrator) can be identified among young people with

180 VI?

181 The following hypotheses have been formulated:

182 a) Male students with VI spend more time online and vary in the frequency of Internet activities 183 compared to female counterparts. 
184 b) Involvement in specific Internet activities is characterized by a more frequent use of the Internet

185 for (i) learning purposes and (ii) social media than discussion forums, blogs, and online shopping 186 among young people with VI.

187 c) Male students with VI engage in particular online risky behaviours (downloading software 188 illegally without valid license, hacking and accessing pornographic content) more frequently than 189 female students.

190 d) Students with VI are more likely to be victims than perpetrators of electronic aggression.

191 e) Online risky behaviours and time spent on the Internet are positive predictors of all forms of 192 engagement in electronic aggression (victim, perpetrator, witness) among young people with VI.

\section{Material and Methods}

\section{Selection procedure}

195 The sampling procedure comprised several stages. Firstly, schools were randomly selected from 196 among nine Polish special-needs schools for the blind and partially sighted. All students aged 13-

19724 years old from the lower-secondary and upper-secondary classes were invited to participate in 198 the study. The age threshold of our group is related to the fact that Polish students with disabilities 199 have the possibility to extend their education time up to 24 years of age. The inclusion criteria for 200 students were as follows: confirmation of VI according to the International Classification of 201 Diseases (ICD-10, 2014), presence during the day of data collection and formal consent to take 202 part in the study, also from parents in the case of students under 18. Parents and participants 203 received written information about the study with the consent form before the survey. The 204 approved and signed consent in the paper form had to be delivered to persons supervising the 205 administrative course and it was a prerequisite for inclusion in the study. To make sure that all 206 participants with VI understood the conditions of the survey, the information about the project and 207 the possibility of withdrawing from the survey at any time was presented before the survey. This 208 information was written in Braille, large font and read aloud to all respondents just before the 209 survey. The only exclusion criterion was the presence of a diagnosed physical or mental disability 210 other than VI. The project was approved by the Bioethics Committee of the Medical University of $211 \operatorname{Lodz}($ No RNN/802/14/KB).

\section{Participants}

213 A total of 1018 respondents met the criteria of participation in the survey. The withdrawal from 214 research during implementation, lack of data, as well as failure to obtain consent for the 
215 participation were the main reasons why 490 respondents with VI (boys: 259; girls: 231), aged 13-

21624 years $(17.9 \pm 2.48)$ were recruited. The students who admitted to using the Internet were blind

$217(\mathrm{~N}=70 ; 14.3 \%)$ or partially sighted $(\mathrm{N}=420 ; 85.7 \%)$. Additional information regarding the severity

218 of impairment or socioeconomic background was not collected as it is considered sensitive data in

219 Poland. The participants comprised two subgroups: the lower-secondary students $(\mathrm{N}=157 ; 32.0 \%)$

220 and upper-secondary students $(\mathrm{N}=333 ; 68.0 \%)$.

\section{Measurement tool}

222 The survey was conducted under the guidance of a trained team: a public health specialist and a 223 psychologist; caregivers and teachers were absent during the survey. A self-administered 224 questionnaire was created and prepared in Braille or large font for the needs of this study. In the 225 questionnaire, questions on sociodemographic variables included gender, age (birth year) and type 226 of school. The first section recorded mean time of Internet sessions including time spent during 227 schooldays and weekends in minutes. Time spent on online activities on computers and mobile 228 devices was estimated on the basis of participants' declarations. In the next section, frequency of 229 online activities, such as communicating via the Internet, SNS, discussion forums, downloading 230 of MP3, music or software files, e-mails, searching for information for learning purposes, online 231 shopping, blogs were considered when the nature of the Internet use was described [36]. The 232 response options to ten items indicating online activities on the Likert scale ranged from: 233 never/almost never, sometimes, almost always/always. The third part of the questionnaire 234 comprised seven items on a five-point scale about types of Internet activities involving risky 235 behaviours (downloading software illegally without a valid license, publication of photos and 236 movies on YouTube without permission of their owners, hacking, communication with a person 237 promoting violence, posting information about sex, viewing websites with sexual content and 238 gambling online) which were taken into consideration [36]. The final section was devoted to 239 electronic aggression involvement. Our primary objective was to identify and describe tendencies 240 regarding electronic aggression among young people with three roles: perpetrators, victims, and 241 witnesses. A perpetrator was defined as a person who had threatened or offended another person

242 via the Internet. Victims were persons who had been threatened or offended by another person and 243 a witness was a person who had been exposed to the situation in which someone had been 244 threatening or offending others via the Internet [38]. This section used a five-point Likert scale 
245 (never, almost never, sometimes, almost always, always) about perpetrating, being the victim or 246 witnessing electronic aggression.

247 Statistical analyses

248 The nonparametric Mann-Whitney U-test was used to compare subgroups with regard to the 249 amount of time spent online. The assessment of the frequency of risky behaviours and ways of 250 using the Internet was made using the chi-square test of independence. In the case of fewer than 5 251 cases the Yates correction was included. To determine whether electronic aggression (being a 252 perpetrator, a victim, or a witness) could be predicted by risky Internet behaviours, three separate 253 ordinal logistic regression analyses were conducted. The criterion for inclusion of the predictors 254 in the final logistic regression models was based on performing initially separate logistic regression 255 equations with one explanatory variable. Based on the significance level $(\mathrm{p}<0.05)$, the predictor 256 was either used in the final model with multiple predictors or excluded from further analyses 257 ( $\mathrm{p}<0.05)$. P-value lower than 0.05 was considered to be significant.

\section{RESULTS}

259 The frequency and nature of Internet use

260 The mean time dedicated to Internet use was longer during school-free days compared to 261 schooldays (193.0 $\min \pm 222.9$ vs $88.3 \min \pm 123.8 ; \mathrm{z}=14.414 ; \mathrm{p}=0.000)$ in the total group. Over $26260 \%(\mathrm{~N}=299)$ of all participants were online up to 2 hours on schooldays, and almost $66 \%(\mathrm{~N}=$ 263 323) of them usually spent up to 3 hours at weekends. Male students spent more time on the 264 Internet than female students both on schooldays $(97.8 \mathrm{~min} . \pm 140.9$ vs $77.7 \mathrm{~min} \pm 100.7)$ and at 265 weekends (207.2 $\pm 234.4 \mathrm{~min}$ vs $176.6 \mathrm{~min} \pm 208.1)$. Students from upper-secondary schools spent 266 more time on the Internet than those from lower-secondary schools on schooldays $(96.6 \pm 135.2$ $267 \mathrm{~min}$ vs $70.0 \mathrm{~min} \pm 91.7)$ and during school-free days (202.4 $\min \pm 209.3$ vs $172.2 \mathrm{~min} \pm 228.4)$.

268 Half of the students used the Internet always or almost always for social networking or to obtain 269 information needed for school. Female youth used SNS statistically more often than male youth,

270 but male students downloaded MP3, software or music files or commented on discussion forums 271 statistically more often than females. There were no statistical differences between lower and 272 upper-secondary school students with regard to almost all types of Internet use. The only difference 273 concerned the fact that students from upper-secondary schools read or sent more e-mails $(\mathrm{N}=66$; $27420.8 \%$ vs $\mathrm{N}=15 ; 9.9 \% ; \mathrm{Chi}^{2}=14.325 ; \mathrm{p}=0.0008$, respectively] and they also statistically more often 
275 used computers to obtain information for knowledge development [N=176;55.3\% vs $N=47$;

$\left.27631.3 \% ; \mathrm{Ch}^{2}=23.38 ; \mathrm{p}=0.00001\right]$ than students from lower-secondary schools (Table 1 ).

\section{Online risky behaviours}

278 In the sample, downloading music files and software without a license $(\mathrm{N}=161 ; 34.2 \%)$ and 279 viewing online sexual sites $(\mathrm{N}=69 ; 14.4 \%)$ were most frequently indicated as performed 280 sometimes or regularly. Male students engaged in all risky behaviours more often than female 281 students. They statistically more often downloaded software illegally and hacked, published, and 282 viewed sites with sexual content and gambled online (Table 2). Students from upper-secondary 283 schools downloaded only software illegally always/almost always statistically more often than 284 those from lower-secondary schools [ $\mathrm{N}=32$ (9.9\%) vs $\mathrm{N}=11$ (74\%); $\left.\mathrm{Chi}^{2}=12.596 ; \mathrm{p}=0.0018\right]$.

\section{Electronic aggression}

286 In our sample almost $52 \%(\mathrm{~N}=241)$ of students witnessed someone experiencing some form of 287 violence on the Internet. Every fifth student ( $\mathrm{N}=98)$ experienced being a victim, and almost $12 \%$ $288(\mathrm{~N}=56)$ of them were perpetrators of threating or offending others on the Internet. However, no 289 statistical differences were identified confirmed in this aspect. Although male youth had higher scores in every dimension of aggression more often than female youth, there were no statistically significant differences related to gender (Table 3). There were also no statistical differences between students from lower- and upper-secondary schools regarding the frequency of being a witness, a victim or a perpetrator of electronic aggression.

\section{Ordinal logistic regression models explaining electronic aggression}

295 In order to identify the predictors of electronic aggression (witnessing), the following variables were included in multiple logistic regression: downloading software illegally without valid license, hacking, communication with a person promoting violence, viewing sexual images online and amount of time spent on the Internet on schooldays and at weekends. It was shown that two out of four variables had significant predictive power for distinction between witnessing or nonwitnessing electronic aggression. Those included: communication with a person promoting violence and the amount of time spent on the Internet during school or school-free days. It was shown that those who communicated occasionally with a person promoting violence were three times more likely to be engaged in electronic aggression as a witness when compared to those who did not have such experience $(\mathrm{OR}=3.07 ; \mathrm{p}<.05)$. No significant relationship was found between 
306 aggression as an observer $(\mathrm{OR}=1.97, \mathrm{p}>.05)$. It turned out - the ratio was approximately four to

307 one - that the excessive Internet use during weekends (over four hours per day) would be

308 associated with observing electronic aggression $(\mathrm{OR}=3.81 ; \mathrm{p}<.01)$. Spending between two to four

309 hours online per day during weekends did not significantly affect witnessing electronic aggression

$310(\mathrm{OR}=1.97, \mathrm{p}<.05)$. The ratios for other variables were not significant (Table 4).

311 In the second ordinal regression model it was determined which independent variables had

312 statistically significant effect on being engaged in electronic aggression as a victim. The ratio for

313 pupils communicating occasionally with those who promoted violence and, in this way, becoming

314 the victims of electronic aggression was $3.26(\mathrm{p}<0.01)$ of that for non-communicating pupils. The

315 odds were higher among those who communicated very often $(\mathrm{OR}=5.52, \mathrm{p}<.05)$. Engagement in

316 electronic aggression as a victim was almost three times more frequent if participants were online

317 one hour per day during school- free days. The odds were higher among the participants who used

318 the Internet between two and four hours per day during weekends $(O R=3.23, p<0.01)$ and when

319 the screen time was more than four hours $(\mathrm{OR}=2.57, \mathrm{p}<.05$, respectively). Other variables did not

320 explain the engagement in electronic aggression as a victim (Table 4).

321 In the final ordinal regression model, it was determined that engagement in electronic aggression

322 as a perpetrator was explained by communicating with a person promoting violence and time

323 online during school days. Participants who responded "occasionally" with reference to

324 communicating with a person promoting violence were engaged in electronic aggression as

325 perpetrators over four times more often than non-communicating participants. The odds were

326 lower and not significant among those reporting to communicate "frequently" with a person

327 promoting violence $(\mathrm{OR}=3.32, \mathrm{p}>.05)$. An increase in Internet time (two to three hours per day

328 during school days and more than three hours vs less than two hours) were associated with higher

329 odds of being engaged in electronic aggression as a perpetrator $(\mathrm{OR}=3.05, \mathrm{p}<.05$ and $4.02, \mathrm{p}<.05$,

330 respectively). No significant odds increase or decrease were found for other independent variables

331 explaining an engagement in electronic aggression as a perpetrator (Table 4).

332 DISCUSSION

333 Our results showed that the mean time spent on the Internet during school-free days was over twice

334 as long as during schooldays. Male students were online longer than female students both during

335 schooldays and school-free days. These results confirmed our primary hypothesis. The tendency

336 identified is consistent with the results of the previous study conducted recently among Polish 
337 adolescents from mainstream schools [4]. It should also be noted that the mean time dedicated to

338 online activities increases with age among participants of this study. We could predict that it is

339 connected with greater focus on learning activities or higher digital competencies among older

340 students with VI.

341 Our study also confirmed that the Internet plays a very important role in knowledge development

342 among students with VI. Indeed, access to e-resources is crucial for self-development and

343 independence during school time and in adulthood among the members of this group. The online

344 activities were mainly used for social networking or getting information to develop school

345 knowledge, which confirms our second hypothesis. These results are very close to the previous

346 preliminary study conducted among pupils with VI [36]. Another study revealed that using online

347 chat had a positive impact on the well-being of people with VI but searching for disability-related

348 information or participation in online support groups influenced them negatively [39], which may

349 be explained by the stress built up during information search and the focus on mitigating one's

350 own deficits rather than accepting them [39]. We also believe that focusing on disability-related

351 topics can make it difficult to move out of thinking of oneself as "disabled" and into full inclusion

352 in society. Yet another study showed that access to the Internet provides people with disabilities

353 with the possibility to communicate with friends, spend and enjoy leisure time [40]. As explained

354 by the compensation model, if someone is socially inactive off-line, he or she benefits more from

355 using the Internet [41].

356 Downloading music files and software without a license and viewing sites with sexual content

357 were the most common risky behaviours among our students with VI. These results are consistent

358 with the preliminary report which indicated the same tendency [36]. It should be added that one in

359 five students with VI had experiences with on-line pornography and this prevalence is nearly twice

360 as among Polish non-VI peers [4]. The third hypothesis regarding gender disparities in the

361 frequency of risky behaviours was confirmed. Generally, male students engaged in all risky

362 behaviours more often than female students, including downloading software illegally and

363 hacking. Moreover, the male participants of this study viewed websites with sexual content more

364 often than their female counterparts. This results are consistent with a pilot study [36].

365 The aspect of sexuality seems to be worth analysing in the context of young people with VI. As

366 sexuality starts to play an important role in puberty, it is natural that adolescents search for

367 knowledge, also on the Internet, and develop their own norms and attitudes towards sex [42]. At 
368 the same time, however, there appears the risk of exposure to specific manifestations of violence, 369 sexting, negative stereotypes, or dehumanization [43]. From this point of view, young people with

370 VI, who experience difficulties in forming intimate relationships in real life and try to compensate

371 for it in the virtual world, can be more exposed to sexual online violence. Still, it seems 372 understandable that youth with VI search for sex and sexuality-related information, especially 373 given that they have diminished possibilities to acquire knowledge by observation or contact with 374 peers, compared to young people without sensory deficits, and when sex education at home or 375 school is not enough or is not tailored to their specific needs [44].

376 Our study showed that more participants with VI were perpetrators of threating or offending others 377 on the Internet than students without disabilities from Polish schools [4]. Before the study we 378 hypothesized that respondents with VI are more likely to be victims than perpetrators of electronic 379 aggression. Although the results were not statistically significant, the highest scores were observed 380 for witnessing electronic aggression, and there were more victims than perpetrators of online 381 aggression. There were also no statistical differences between genders in this respect, but boys 382 experienced being a witness, a victim, or a perpetrator of electronic aggression more often than 383 girls in our study group. Although our results are not the basis for generalization, a particular attention should be paid to online violence among young people with a problem of visible bodily injury, disability or a serious health problem. Acts of aggression include different phenomena such as unpleasant comments in one-to-one online communication, unpleasant public comments, revealing the secrets of particular people in online communication, the dissemination of disgraceful information concerning a person. Moreover, the online material has some additional characteristics namely durability, copyability and the possibility of access by an invisible audience. The published information widely available in this way increases the risk of losing control regardless of the will of those involved (including the original perpetrators). It is recommended

392 that we should educate people with disabilities by raising awareness of building their own online

393 image forming the right attitudes of emotional resilience towards other people [34].

394 Furthermore, communication with a person promoting violence and the mean time of online 395 activity are significant predictors of the likelihood of being a witness, a victim, or a perpetrator of

396 electronic aggression. Our study also showed that the more time students spend on the Internet 397 during school-free days, the more likely they are to become a witness or a victim. The risk of 398 becoming a perpetrator of electronic aggression depends on the online time during schooldays. It 
399 was also revealed that students with VI having occasional online contact with a person promoting 400 violence become three times more often a witness or a victim, and four times more often a 401 perpetrator of electronic aggression. They are even five times more likely to become the victims 402 of electronic aggression if they come into contact with such a person often or very often, compared 403 to those who have never communicated with the perpetrator of aggression. The constant access of 404 perpetrators to their victims on Internet is the mechanism that makes electronic aggression even 405 more destructive than the traditional one [20]. Many young people, mostly because of using SNS, 406 are "always connected" and they are constantly exposed to harmful content and behaviours 407 towards them. Even if they decide to be offline, negative information about them could be further 408 disseminated over the Internet [20].

409 Our findings are not free from limitations. The first limitation is the cross-sectional design that 410 makes some causal reasoning impossible. Further, a self-administrated survey was used to enable 411 anonymous participation in the study. Respondents were supported by researchers and teachers 412 were not present during the process of filling in questionnaires, which was meant to enhance 413 honesty of the answers provided. Our intention is to repeat the study among young people with VI 414 attending regular schools and take into consideration their parents' and teachers' opinions. 415 Moreover, the results of our research are difficult to compare with the results of other studies of 416 peers without or with disabilities. This is due to the lack of validated diagnostic tools dedicated to 417 people with different disabilities. It is recommended to develop universal study protocols for 418 students with and without disabilities to increase the chances of comparing the results. Finally, 419 qualitative research among different groups of youngsters could be provided in the next step of 420 future research. It will provide a better opportunity to develop diagnostic solutions regarding risky 421 behaviours among participants with and without disabilities. In this way, we believe, our research 422 will contribute to identifying the needs and challenges faced by groups at the risk of social 423 exclusion and, as a result, become a starting point for the development of academic, educational 424 and social initiatives, as well as media literacy, meant to reduce the extent of digital divide and 425 ensure a better quality of life for people with disabilities.

\section{CONCLUSION}

427 Cyberspace with its technological affordances has enabled new proximity dynamics in user-to428 user and user-to-content interactions, as argued by the MPA. Allowing users to transgress time 429 and space boundaries it has considerably extended possibilities of participation and agency. The 
430 safe use of the Internet enables and facilitates information exchange, supports the learning process, 431 provides an opportunity for self-expression and communication with people having similar 432 interests. Yet, however beneficial in educational terms and in the context of social participation 433 using the Internet is, it is also burdened with the risk of exposure to various types of online 434 aggression and otherwise harmful content.

435 Considering the above factors when teaching digital competencies and media literacy we should 436 place particular emphasis on constructive and safe media use among young people with VI. Safety437 related awareness-raising activities should address problems of cyberbulling, electronic 438 aggression, including "digital dating abuse" [45], as well as other online risky behaviours. Sexual 439 health education is also necessary to protect adolescents with VI against sexual violence and ensure 440 proper development within this sphere of psychosocial functioning [46]. Not only students, but 441 also parents, caregivers, teachers and health educators should be confronted with possible risks 442 associated with cyberspace and provided with knowledge about preventive resources, strategies 443 and tools adjusted to the special needs of people with disabilities [47]. Another important and 444 protective factor is developing social skills and enhancing interpersonal contacts in real life to 445 minimize the need to compensate for loneliness on the Internet.

446

447

448

449

450

451

452 453 454 455 456 457 458

\section{References}

1. Bosse I, Renner G, Wilkens L. Social Media and Internet Use Patterns by Adolescents With Complex Communication Needs. Lang Speech Hear Serv Sch. 2020; 4:1024-1036. doi: 10.1044/2020_LSHSS-19-00072.

2. Livingstone S, Mascheroni G and Staksrud E. European research on children's internet use: Assessing the past and anticipating the future. New Media \& Society 2018; 20(3): 1103-1122.

3. EU Kids Online IV Survey. To appear in 2019: The new EU Kids Online survey on children's and young people's online experiences in Europe. Microsoft Word - EU Kids Online IV Survey Information for SIF 181119.docx (hans-bredow-institut.de) (Access, 22.04.2021)

4. Pyżalski J, Zdrodowska A, Tomaczyk Ł, Abramczuk K. Polskie badanie EU Kids Online (Polish research Eu Kids Online).WN, Poznań, 2019.

5. Tahiroglu AY, Celik GG, Uzel M, Ozcan N, Avci A. Internet use among Turkish adolescents. CyberPsychology \& Behavior 2008; 11: 537-543. 
461 6. Patti M. Valkenburg, Jochen Peter. Social Consequences of the Internet for Adolescents: A 462 Decade of Research 2009;February, 1.

463 https://doi.org/10.1111/j.1467-8721.2009.01595.x

464 7. Király O, Potenza MN, Stein DJ, King DL, Hodgins DC, Saunders JB, Griffiths MD, Gjoneska 465 B , Billieux J, Brand M, Abbott MW, Chamberlain SR, Corazza O, Burkauskas J, Sales CMD, 466 Montag C, Lochner C, Grünblatt E, Wegmann E, Martinotti G, Lee HK, Hans-Jürgen Rumpf HJ, Castro-Calvo J, Rahimi-Movaghar A, Higuchi S, Menchon JM, Zohar J, Pellegrini L, Walitza S, Fineberg NA, Demetrovics Z. Preventing problematic internet use during the COVID-19 pandemic: Consensus guidance. Comprehensive Psychiatry 2020; 100, 152180. https://doi.org/10.1016/j.comppsych.2020.152180

8. KhosraviNik M, Esposito E. Online Hate, Digital Discourse and Critique: Exploring DigitallyMediated Discursive Practices of Gender-Based Hostility. Lodz Papers in Pragmatics 2018; 14(1): 45-58.

9. Kopytowska M. Introduction: Discourses of Hate and Radicalism in Action. In Contemporary 476 Discourses of Hate and Radicalism across Space and Genres, ed. by Monika Kopytowska M. Amsterdam: John Benjamins; 2017.

10. Pyżalski J. Electronic aggression of children and adolescents - various dimensions of the phenomenon. Quarterly Child Abused 2009; 1(26):12-27.

11. KhosraviNik M. Social media techno-discursive design, affective communication and contemporary politics. Fudan Journal of the Humanities and Social Sciences 2018; 11(4): 427482 442. doi:10. 1007/s40647-018-0226-y

12. Kopytowska M. Blogging as the Mediatization of Politics and a New Form of Social Interaction. A Case Study of Polish and British Political Blogs. In Analyzing Genres in Political Communication, ed. by Cap P\& Okulska U. Amsterdam: John Benjamins; 2013.

13. Kopytowska M. Mediating Identity, Ideology and Values in the Public Sphere: Towards a New Model of (Constructed) Social Reality. Lodz Papers in Pragmatics 2015; 11(2): 133-156.

14. Pyżalski J. Elektroniczna agresja rówieśnicza - ustalenia empiryczne ostatniej dekady In 488 Uzależnienia behawioralne i zachowania problemowe młodzieży. Teoria, Diagnoza, Profilaktyka, Terapia. (Electronic peer aggression - empirical findings of the last decade. In Behavioral addictions and problem behaviors of adolescents. Theory, Diagnosis, Prevention, Therapy ed. by Jarczyńska J. Bydgoszcz; 2014, pp 39-47 
492

493

494

495

496

497

498

499

500

501

502

503

504

505

506

507

508

509

510

511

512

513

514

515

516

517

518

519

520

521

522

http://www.wydawnictwotest.ukw.edu.pl/wpcontent/uploads/2014/12/Druk Uzaleznienia.pd $\underline{\mathrm{f} \# \text { page }=33}$

15. Kopytowska M. Proximization, Prosumption and Salience in Digital Discourse: On the Interface of Social Media Communicative Dynamics and the Spread of Populist Ideologies. [Special Issue on Social Media Critical Discourse Studies]. Critical Discourse Studies 2020. doi: $10.1080 / 17405904.2020 .1842774$.

16. Postmes T, Spears R \& Lea M. Intergroup differentiation in computer-mediated communication: Effects of depersonalization. Group Dynamics 2002; 6(1): 3-16.

17. Santana AD. Virtuous or Vitriolic. Journalism Practice 2014; 8(1): 18-33.

18. Murabak A. A theoretical framework on adolescents' risk-taking behaviours while using the Internet in Australia. International Journal of Technology, Knowledge \& Society 2012; 5: 2737.

19. Hasebrink U, Görzig A, Haddon L, Kalmus V, Livingstone S. Patterns of risk and safety online. In-depth analyses from the EU Kids Online survey of 9-16 year old and their parents in 25 countries. LSE, London: EU Kids Online; 2011.

20. Pyżalski J. Agresja elektroniczna i cyberbullying jako nowe ryzykowne zachowania młodzieży (Electronic aggression and cyberbullying as new risky behaviors of young people).Kraków: Oficyna Wydawnicza „Impuls”; 2012.

21. Kowalski RM, Giumetti GW, Schroeder AN, Lattanner MR. Bullying in the digital age: A critical review and meta-analysis of cyberbullying research among youth. Psychological Bulletin 2014; 140(4): 1073-1137.

22. Tsitsika A, Janikian MJ, Wójcik S, Makaruk K, Tzavela E, Tzavara C, Greydanus D, Merrick J, Richardson C. Cyberbullying Victimization Prevalence and Association with internalizing and externalizing problems among adolescents in six European countries. Computer in Human Behavior 2015; 51.

23. Beyens I, Vandenbosch L, Eggermont S. Early Adolescent Boys’ Exposure to Internet Pornography: Relationships to Pubertal Timing, Sensation Seeking, and Academic Performance. Journal of Early Adolescence 2015, 35(8): 1045-1068.

24. Martellozzo E, Monaghan A, Davidson J, Adler J. Researching the Affects That Online Pornography Has on U.K. Adolescents Aged 11 to 16. Sage Open 10(11) https://doi.org/10.1177/2158244019899462 
523 25. Villani D, Florio E, Castelli I. Adolescents' beliefs about peers' engagement in an online self-

524 harm challenge: exploring the role of individual characteristic throught a latent class analysis.

525 CyberPsychology, Behavior and Social Networking 2015; 22, 11: 684-691.

526 26. Tsitsika A, Janikian M, Tzavela EC, Schoenmakers TM, Olafsson K, Halapi E, Tzavara C, 527 Wojcik S, Makaruk K, Critselis E, Müller KW, Dreier M, Holtz S, Wölfling K, Iordache A, 528 Oliaga A, Chele G, Macarie G, Richardson C. Internet use and Internet addictive behaviour 529 among European adolescents: A cross-sectional study. EU NET ADB, 2012. (http://youth-health.gr/media/2016/03/eu-net-adb-quantitative-report-d6-2-r-june2013_2.pdf)

27. Anderson M. A Majority of Teens Have Experienced Some Form of Cyberbullying, Report. PEW Research Center. Washington; 2018. (http://www.pewInternet.org/2018/09/27/a-majority-of-teens-have-experienced-some-formof-cyberbullying/)

28. Argen A, Kiellberg A, Hemminsson H. Digital participation? Internet use among adolescents with and without intellectual disabilities: A comparative study. New Media and Society 2020; 22(12): 2128-2145.

29. Parimala R, Wood D, Newman L, Lawry J. Why aren't you on Facebook? Patterns and experiences of using the internet among young people with disabilities. Technology \& Disabilitity 2012; 2:149-162.

30. Duplaga M. Digital divide among people with disabilities: Analysis of data from a nationwide study for determinants of Internet use and activities performed online. PLoS One 2017;12(6):e0179825. doi: 10.1371/journal.pone.0179825. PMID: 28662125; PMCID: PMC5491040.

31. Pfeiffer JP, Pinquart M. Computer use of adolescents with and without visual impairment. 548 Technology \& Disability 2013; 23(2): 99-106.

32. Web Content Accessibility Guidelines (WCAG) Overview. https://www.w3.org/WAI/standards-guidelines/wcag/ (Access: 29.04.2021)

33. Melissa W, Mitchel KJ, Jones LM, Turner HA. Peer harassment among youths with different disabilities: impact of harassment online, in person, and in mixed online and in-person incidents. Children\& Schools 2019; 41(1): 17-24. 
553 34.Plichta P, Pyżalski J, Barlińska J. Cyberbullying Versus Self-Image Creation on the Internet:

554

555

556

557

558

559

560

561

562

563

564

565

566

567

568

569

570

571

572

573

574

575

576

577

578

579

580

581

582

Are the Underlying Mechanisms Different in Young Adults with Disabilities?. Interdyscyplinarne Konteksty Pedagogiki Specjalnej 2018; 20:101-122.

35. Pinquart M. Systematic Review: Bullying Involvement of Children With and Without Chronic Physical Illness and/or Physical/Sensory Disability-a Meta-Analytic Comparison With Healthy/Nondisabled Peers. J Pediatr Psychol. 2017; 42(3): 245-259. doi:10.1093/jpepsy/jsw081

36. Wrzesińska M, Tabała K, Stecz P. The online behavior of pupils with visual impairment: A preliminary report. Disabil Health J. 2016; 9(4):724-729. doi:10.1016/j.dhjo.2016.04.004

37. Chetty N, Alathur S. Hate Speech Review in the Context of Online Social Networks. „Aggression \& Violent Behavior” 2018; 40:108-118.

38. Jenaro C, Flores N, Vega V, Cruz M, Pérez MC, Torres VA. Cyberbullying among adults with intellectual disabilities: Some preliminary data. Res Dev Disabil. 2018; 72: 265-274. doi:10.1016/j.ridd.2017.12.006

39. Smedema SM, McKenzie AR. The relationship among frequency and type of Internet use, perceived social support, and sense of well-being in individuals with visual impairments. Disability and Rehabilitation 2010; 32(4):317-25. doi: 10.3109/09638280903095908

40. Shpigelman CN, Gill CJ. Facebook use by persons with disabilities. J.Comput. Mediat. Comm. 2014; 19: 610-624.

41. Lathouwers K, de Moor J, Didden R. Access to and use of Internet by adolescents who have a physical disability: a comparative study. Res Dev Disabil. 2009; 30(4): 702-711. doi:10.1016/j.ridd.2008.09.003

42. Naezer M. From Risky Behaviour to Sexy Adventures: Reconceptualising Young People's Online Sexual Activities. „Culture, Health \& Sexuality” 2018; 20(6): 715-729.

43. Stanley N, Barter C, Wood M, Aghtaie N, Larkins C, Lanau A, Överlien C. Barter C, Wood M. Pornography, Sexual Coercion and Abuse and Sexting in Young People's Intimate Relationships: A European Study. Journal of Interpersonal Violence 2018; 33(19): 2919-2944. 44. Czerwińska K. Edukacja seksualna dzieci i młodzieży z niepełnosprawnością wzroku. [Sexual education of children and adolescents with visual disabilities]. Kwartalnik Naukowy Fides et Ratio 2019; 39(3): 275-289.

Peer] reviewing PDF | (2021:01:57445:2:1:NEW 18 Sep 2021) 
583 45. Hinduja S, Patchin JW. Digital Dating Abuse Among a National Sample of U.S. Youth. Journal 584 of Interpersonal Violence 2020; 1-21.

$585 \quad$ 1.o0r.g1/7.171/0778/80688262065015919889977344

586 46.Hafiar H, Sjafirah NA, Priyatna CC, Lukman S, Syuderajat F. Precaution towards access to 587 pornographic content through the internet by students with visual impairment. Library $588 \quad$ Philosophy and Practice 2020; 3761.

589 47. Symons K, Ponnet K, Emmery K, Walrave M, Heirman W. Parental knowledge of adolescents' 590 online content and contact risks. Journal of Youth and Adolescence 2017; 46(2): 401-416.

591

\section{Ethics declaration}

593 The project was approved by the Bioethics Committee of the Medical University of Lodz (No $594 \mathrm{RNN} / 802 / 14 / \mathrm{KB})$

595 Competing interests: None declared. 


\section{Table 1 (on next page)}

Types of Internet activity among young people with visual impairment including gender

A row data and percentages are involved in the table. 
Table 1. Types of Internet activity among young people with visual impairment including gender

\begin{tabular}{|c|c|c|c|c|c|c|c|c|c|}
\hline & \multicolumn{3}{|c|}{ Total } & \multicolumn{3}{|c|}{ Boys } & \multicolumn{3}{|c|}{ Girls } \\
\hline & $\begin{array}{c}\text { Never/ } \\
\text { almost } \\
\text { never }\end{array}$ & Sometimes & $\begin{array}{c}\text { Always/ } \\
\text { almost } \\
\text { always }\end{array}$ & $\begin{array}{c}\text { Never/ } \\
\text { almost } \\
\text { never }\end{array}$ & Sometimes & $\begin{array}{c}\text { Always/ } \\
\text { almost } \\
\text { always }\end{array}$ & $\begin{array}{c}\text { Never/ } \\
\text { almost } \\
\text { never }\end{array}$ & Sometimes & $\begin{array}{c}\text { Always/ } \\
\text { almost } \\
\text { always }\end{array}$ \\
\hline & $\mathrm{N}(\%)$ & $\mathrm{N}(\%)$ & $\mathrm{N}(\%)$ & $\mathrm{N}(\%)$ & $\mathrm{N}(\%)$ & $\mathrm{N}(\%)$ & $\mathrm{N}(\%)$ & $\mathrm{N}(\%)$ & $\mathrm{N}(\%)$ \\
\hline Conversation via the Internet (chats, Skype) & $125(26.9)$ & $204(43.9)$ & $136(29.2)$ & $59(23.8)$ & $117(47.2)$ & $72(29.0)$ & $66(30.4)$ & $87(40.1)$ & $64(29.5)$ \\
\hline SNS & $85(18.0)$ & $136(28.9)$ & $250(53.1)$ & $55(22.1)$ & $79(31.7)$ & $115(46.2)$ & $30(13.5)$ & $57(25.7)$ & $135(60.8)^{1}$ \\
\hline Discussion forums & $288(61.5)$ & $145(31.0)$ & $35(7.5)$ & $138(55.6)$ & $84(33.9)$ & $26(10.5)$ & $150(68.2)$ & $61(27.7)$ & $9(4.1)^{2}$ \\
\hline MP3, music and software uploading & $101(21.5)$ & $198(42.0)$ & $172(36.5)$ & $55(22.1)$ & $87(34.9)$ & $107(43.0)$ & $46(20.7)$ & $111(50.0)$ & $65(29.3)^{3}$ \\
\hline e-mails & $179(38.2)$ & $208(44.5)$ & $81(17.3)$ & $91(36.7)$ & $109(44.0)$ & $48(19.3)$ & $88(40.0)$ & $99(45.0)$ & $33(15.0)$ \\
\hline Searching for information for learning purpose & $35(7.5)$ & $210(44.9)$ & $223(47.6)$ & $18(7.3)$ & $123(49.6)$ & $107(43.1)$ & $17(7.7)$ & $87(39.6)$ & $116(52.7)$ \\
\hline Online shopping & $303(64.3)$ & $143(30.4)$ & $25(5.3)$ & $160(64.3)$ & $73(29.3)$ & $16(6.4)$ & $143(64.4)$ & $70(31.5)$ & $9(4.1)$ \\
\hline$B \operatorname{logs}$ & $344(73.2)$ & $88(18.7)$ & $38(8.1)$ & $179(72.2)$ & $50(20.2)$ & $19(7.6)$ & $165(74.3)$ & $38(17.1)$ & $19(8.6)$ \\
\hline
\end{tabular}

$4 \quad{ }^{1} \mathrm{Chi}^{2}=11.00 ; p=0.004 ;{ }^{2} \mathrm{Chi}^{2}=10.77 ; p=0.005 ;{ }^{3} \mathrm{Chi}^{2}=12.46 ; p=0.002$ 
Table 2 (on next page)

Online risky behaviours and gender

A row data and percentages are involved in the table. 


\section{Table 2. Online risky behaviours and gender}

\begin{tabular}{|c|c|c|c|c|c|c|c|c|c|}
\hline \multirow[t]{3}{*}{ Risky behaviours } & \multicolumn{3}{|c|}{ Total } & \multicolumn{3}{|c|}{ Boys } & \multicolumn{3}{|c|}{ Girls } \\
\hline & $\begin{array}{c}\text { Never/ } \\
\text { almost } \\
\text { never }\end{array}$ & Sometimes & $\begin{array}{l}\text { Always/ } \\
\text { almost } \\
\text { always }\end{array}$ & $\begin{array}{c}\text { Never/ } \\
\text { almost } \\
\text { never }\end{array}$ & Sometimes & $\begin{array}{c}\text { Always/ } \\
\text { almost } \\
\text { always }\end{array}$ & $\begin{array}{c}\text { Never/ } \\
\text { almost } \\
\text { never }\end{array}$ & Sometimes & $\begin{array}{c}\text { Always/ } \\
\text { almost } \\
\text { always }\end{array}$ \\
\hline & $\mathrm{N}(\%)$ & $\mathrm{N}(\%)$ & $\mathrm{N}(\%)$ & $\mathrm{N}(\%)$ & $\mathrm{N}(\%)$ & $\mathrm{N}(\%)$ & $\mathrm{N}(\%)$ & $\mathrm{N}(\%)$ & $\mathrm{N}(\%)$ \\
\hline $\begin{array}{l}\text { Downloading the software illegally without valid } \\
\text { license }\end{array}$ & $310(77.2)$ & $118(25.1)$ & $43(9.1)$ & $144(57.8)$ & $66(26.5)$ & $39(15.7)$ & $166(74.8)$ & $52(23.4)$ & $4(1.8)^{1}$ \\
\hline $\begin{array}{l}\text { Publication of photos and movies on YouTube } \\
\text { without permission of their owners }\end{array}$ & $433(90.8)$ & $34(7.1)$ & $10(2.1)$ & $223(88.5)$ & $22(8.7)$ & $7(2.8)$ & $210(93.3)$ & $12(5.3)$ & $3(1.3)$ \\
\hline Hacking & $417(87.4)$ & $42(8.8)$ & $18(3.8)$ & 201(79.8) & $34(13.5)$ & $17(6.7)$ & $216(96.0)$ & $8(3.6)$ & $1(0.4)^{2}$ \\
\hline Communication with persons promoting violence & $433(90.6)$ & $31(6.5)$ & $14(2.9)$ & $225(88.9)$ & $17(6.7)$ & $11(4.3)$ & $208(92.5)$ & $14(6.2)$ & $3(1.3)$ \\
\hline Publication information regarding sex & $445(93.3)$ & $18(3.8)$ & $14(2.9)$ & $227(90.1)$ & $13(5.2)$ & $12(4.7)$ & $218(96.9)$ & $5(2.2)$ & $2(0.9)^{3}$ \\
\hline Viewing sexual pages online & $409(85.6)$ & $56(11.7)$ & $13(2.7)$ & $198(78.6)$ & $41(16.3)$ & $13(5.1)$ & 211(93.4) & $15(6.6)$ & $0(0.0)^{4}$ \\
\hline Gambling online & $440(92.4)$ & $27(5.7)$ & $9(1.9)$ & $226(89.7)$ & $17(6.7)$ & $9(3.6)$ & $214(95.5)$ & $10(4.5)$ & $0(0.0)^{5}$ \\
\hline
\end{tabular}

3

${ }^{1} \mathrm{Chi}^{2}=30.26 ; p=0.000 ;{ }^{2} \mathrm{Chi}^{2}=29.42 ; p=0.000 ;{ }^{3} \mathrm{Chi}^{2}=9.38 ; p=0.009 ;{ }^{4} \mathrm{Chi}^{2}=24.14 ; p=0.001 ;{ }^{5} \mathrm{Chi}^{2}=9.52 ; p=0.008$

4 


\section{Table 3(on next page)}

The frequency of electronic aggression (witness, victim, perpetrator) in e-mails, or in social media

A row data and percentages are involved in the table. 
1 Table 3. The frequency of electronic aggression (witness, victim, perpetrator) in e-mails, or 2 in social media

3

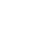

Have you ever witnessed someone Behaviours threatening or offending other people via the Internet?

Have you ever been threatened or offended by another person via the Internet?

Have you ever threatened or offended

\begin{tabular}{cc}
\hline $\begin{array}{c}\text { Never/ } \\
\text { almost } \\
\text { never }\end{array}$ & Som \\
\hline $\mathrm{N}(\%)$ & \\
\hline $119(49.4)$ & 106
\end{tabular}
Boys

$$
\text { 196(77.2) }
$$

49(19.3)

220(86.6)

$30(11.8)$

\section{Girls}

Always/ Never/ Sometimes

almost

always almost never

$\mathrm{N}(\%)$

$\mathrm{N}(\%)$

$16(6.6)$

105(46.9)

$9(3.5)$

188(82.5)

37(16.2)

3(1.3)

another person via the Internet?

4 


\section{Table 4(on next page)}

Ordinal logistic regression models explaining electronic aggression (witness, victim, perpetrator) with multiple predictors

A row data and percentages are involved in the table. 
1 Table 4. Ordinal logistic regression models explaining electronic aggression (witness,

2 victim, perpetrator) with multiple predictors

\begin{tabular}{|c|c|c|c|}
\hline \multicolumn{4}{|c|}{ Witness } \\
\hline Communication with person promoting violence & OR & $95 \% \mathrm{CI}$ & $\mathbf{P}$ \\
\hline Never/almost never & 1.00 & Ref. & \\
\hline Sometimes & 3.07 & $(1.29-7.32)$ & 0.011 \\
\hline Always/almost always & 1.97 & $(0.44-8.87)$ & 0.374 \\
\hline \multicolumn{4}{|l|}{ Time of online activity during school-free days (in $h$ ) } \\
\hline 0 & 1.00 & Ref. & \\
\hline less 1 & 1.91 & $(0.78-4.66)$ & 0.155 \\
\hline from 1 to 2 & 1.69 & $(0.70-4.08)$ & 0.241 \\
\hline from 2 to 4 & 1.97 & $(0.81-4.79)$ & 0.135 \\
\hline over 4 & 3.81 & $(1.44-10.1)$ & 0.007 \\
\hline \multicolumn{4}{|c|}{ Victim } \\
\hline \multicolumn{4}{|l|}{ Communication with person promoting violence } \\
\hline Never/almost never & 1.00 & Ref. & \\
\hline Sometimes & 3.26 & $(1.40-7.60)$ & 0.006 \\
\hline Always/almost always & 5.52 & $(1.37-22.3)$ & 0.016 \\
\hline \multicolumn{4}{|l|}{ Time of online activity during school-free days (in $h$ ) } \\
\hline 0 & 1.00 & Ref. & \\
\hline less 1 & 2.60 & $(1.23-5.51)$ & 0.012 \\
\hline from 1 to 2 & 3.23 & $(1.50-6.98)$ & 0.003 \\
\hline $\begin{array}{l}\text { from } 2 \text { to } 4 \\
\text { over } 4\end{array}$ & 2.57 & $(1.07-6.13)$ & 0.034 \\
\hline \multicolumn{4}{|c|}{ Perpetrator } \\
\hline \multicolumn{4}{|l|}{ Communication with person promoting violence } \\
\hline Never/almost never & 1.00 & Ref. & \\
\hline Sometimes & 4.07 & $(1.61-10.3)$ & 0.003 \\
\hline Always/almost always & 3.32 & $(0.67-16.5)$ & 0.142 \\
\hline \multicolumn{4}{|l|}{ Time of online activity during school days (in h) } \\
\hline 0 & 1.00 & Ref. & \\
\hline less 1 & 1.57 & $(0.57-4.29)$ & 0.379 \\
\hline from 2 to 3 & 3.05 & $(1.07-8.710)$ & 0.036 \\
\hline over 3 & 4.02 & $(1.23-13.1)$ & 0.021 \\
\hline
\end{tabular}

